\title{
The European Neighborhood Policy: a perspective of the partner countries ${ }^{1}$
}

\author{
Małgorzata ZAJACZKOWSKI \\ Warsaw School of Economics, Poland
}

\begin{abstract}
:
Aim: The aim of the paper is an analysis and assessment of the partner-countries' various positions and interests with regard to the European Neighborhood Policy (ENP). The focus was put on expectations and reservations related to ENP in the partner countries.
\end{abstract}

Design/ research method: The analysis is based on the subject literature related to the ENP. The paper comprises three parts. The first one depicts general geopolitical overview of the ENP. Second part concentrates on partner countries different approaches towards the initiative and the third section is an attempt to examine the neighboring countries' conflicting visions towards the ENP.

Conclusions: The widespread criticism of the outcomes of the ENP is a result of grave geopolitical turbulences, i.e.: the Mediterranean partners have experienced the Arab Spring uprisings and the Eastern neighbors have again found themselves in the orbit of particular interests of Russia. The partner countries' visions and expectations towards the ENP are very diverse. Some of them seek to achieve economic benefits without closer political relations with the EU, others strive to achieve membership in the EU which is perceived as an inherent element of the process of successful reforms and systemic transformation.

Value of the article: The paper addresses the problem of declining the ENP. The reason is twofold: contradictory interests of the partner countries and second, floppy engagement of the UE's institutions in forging of the ENP policy.

Limitations of the research: The analysis is limited to general political tendencies and line of actions addressed by the ENP partner countries. It resulted both from changes in the ENP agenda as well as international relations and internal turbulences in the regions.

1 This research project has benefited from funding under the Polish "National Science Centre" (NCN) grant titled "European Neighbourhood Policy: (multi-level) governance, the reform process and the prospect of enhanced cooperation in the region", OPUS/HS5, No. 2013/09/B/HS5/04534.

Contact details: Małgorzata Zajączkowski, Warsaw School of Economics, Al. Niepodległości 162, 02554, Warsaw, Poland. E-mail: mgraci@sgh.waw.pl

Received: 10.07.2017, Revised: 11.06.2018, Revised: 28.06.2018, Accepted: 02.07.2018

DOI: http://dx.doi.org/10.29015/cerem.510 
Keywords: European Union (EU), European Neighborhood Policy (ENP), Union for the Mediterranean (UfM), Eastern Partnership (EaP), Deep and Comprehensive Free Trade Area (DCFTA), European integration.

JEL: F02, F15, F59, N74

\section{Introduction}

There is growing negative assessment among the EU's partner countries towards the outcomes of the European Neighborhood Policy (ENP). It resulted from different objectives and expectations towards the program against the provisions put by the EU. Some of the countries strive to achieve closer economic benefits with the EU without aspiring to membership, others seek to attain an accession to the EU which is to be accompanied by successful socio-economic reform and systemic transformation. Instead the EU expresses its willingness to engage with selective ENP members much more on the basis of close association than membership. Additionally the widespread criticism is a consequence of geopolitical turbulences and military crisis in the countries covered by the ENP, i.e.: the Mediterranean partners have experienced the turmoil of the Arab Spring and the Eastern neighbors have again found themselves in the orbit of particular interests of Russia, the apogee of which is the armed conflict in the Eastern Ukraine. The EU is accused of not engaging in resolution of the crisis and the lack of adequate response.

The ENP covers numerous countries from Eastern Europe, Southern Caucasus, North Africa and Middle East which are very diverse and heterogeneous. Many of the partners have never agreed with the proposed "neighborhood" formula and its scope and have failed to make substantial progress in economic, social and political modernizations. Therefore the aim of the paper is the analysis and examination of the partner-countries' various positions and interests with regard to the ENP. The key point is to find the root-causes of their divergent expectations and reservations towards the ENP. The paper comprises three parts. In the first one there was depicted general geopolitical overview of the ENP. Second part concentrates on partner countries different approaches towards the initiative and the third section is an attempt of synthetic analysis of the neighboring countries conflicting visions within the ENP. 


\section{ENP in a nutshell}

The ENP was launched in 2004 with the aim of building new political and economic relations between the EU and its Southern and Eastern neighboring countries through supporting of introduction of reforms and systemic changes in the partner countries. In the South the initiative covered 10 countries: Algeria, Egypt, Israel, Jordan, Lebanon, Libya, Morocco, Palestine, Syria and Tunisia and in the East 6 states: Armenia, Azerbaijan, Belarus, Georgia, Moldova and Ukraine. The main objective of the ENP was to avoid the emergence of new dividing lines between the enlarged EU and its neighbors by engaging of the partner countries in negotiation of reform priorities leading to good governance, rule of law, trade liberalization and civil society representation. The ENP was to go beyond traditional financial assistance provided to the neighboring countries and was assumed to be better suited to the challenges in particular regions. The EU's offer was based on two pillars. First, it was the EU political and economic engagement pledged to increase funds within the ENP programs. Second, it was to be a platform for better economic and political cooperation between the EU as a whole and the partner countries.

The Southern dimension of the ENP was built upon the initiatives of the Barcelona Process and was reinforced by the Union for the Mediterranean (UfM). The latter was established upon the initiative of French President Nicolas Sarkozy in 2008 and has replaced the Euro-Mediterranean Partnership (EMP) which was laid down within the framework of the Barcelona Process. However the ENP and the UfM does not overlap in terms of their membership. It means that Bosnia and Herzegovina, Albania, Montenegro, Monaco, Mauritania and Turkey are members of the UfM but not part of the ENP.

Under the EMP formula there were introduced ambitious long-lasting programs on political, economic and cultural co-operation between the 15 EU Member states and 12 Mediterranean partners with much focus on democratization and sustainable socio-economic prosperity. The cooperation was enhanced by initiating a free trade area between the EU and the partners which was to be implemented by 2010 though Euro-Mediterranean Association Agreements with each of them. Because of the 
mass critics and unsatisfactory results the Barcelona Process was considered a failure at its tenth anniversary in 2005 (Sarto, Schumacher 2005: 25-28).

The Union for the Mediterranean was to reinforce the Southern dimension of the ENP and put a clear distinction between the Eastern and Southern neighbors. It was also an indicator that the approach "one size fits all" applied in the ENP was inadequate to the situation and showed little added value compared to other forms of more traditional bilateral assistance (Koeth 2014: 24). The new initiative was equipped with its own intergovernmental set-up and a limited number of political and economic objectives which meant short term goals of enhancing economic relations and European security ahead of addressing local socio-economic problems (Wouters, Duquet 2013: 22). The program of ENP reinforced by the UfM was to be pursued in two ways: first by multilateral and second bilateral dimension. The multilateral perspective is related to the UfM and its predecessor - the Barcelona Process. The bilateral dimension is complemented by the Association Agreement (AAs) undertaken within the Barcelona Process and the ENP Action Plans within the ENP.

In turn, the Eastern dimension of the ENP is represented by the initiative of Eastern Partnership (EaP) which was launched in 2009. After the admission of Central European Countries to the EU in 2004 and 2007 the Union decided to launch a program which would provide the EU's Eastern neighbors with an alternative to membership a set of incentives for engaging in economic, social and political reforms. However in the view of the EaP's initiators - Poland and Sweden, the EU's membership would mean for the ENP partners the partnership (implicit) goal contrary to the official doctrine of "sharing everything but institutions" (Hett et al. 2015: 3). The concept of "sharing everything but institutions" was issued by the European Commissioner Romano Prodi (Prodi 2002). The initiative was expected to stimulate changes in Eastern Europe by bringing forward internal reform and enhancing intra-regional cooperation. Moreover the EaP highlighted the importance of good neighborly relations, confidence-building measures and the advancement of stability. 
The package of the EaP contains three major elements which if it implemented would improve economic and social situation in the partner countries and their cooperation with the EU. First it is a problem of admission and implementation of the Association Agreements (AAs.) and/or Deep and Comprehensive Free Trade Area (DCFTA). Second goal concerns a visa free regime and the third involves the issue of energy security and a membership in a Energy Community created in 2006 for the Western Balkan countries (Gromadzki 2015: 12-13). Moreover the initiative assumed to develop intraregional cooperation among the partners which would lead to formulate a stable regional block. Against this background not much has been yet achieved. However as a milestone it should be acknowledge the signing of the Association Agreement (AA) including the DCFTA by Ukraine, Georgia and Moldova. All of them expressed interest in deeper integration with the EU having in mind their future membership. In contrast the remaining partners of the EaP Armenia, Azerbaijan and Belarus did not want to continue further integration with the EU and for the time being decided to remain out of the process.

In sum, before its enlargement in 2004 the EU had an institutional framework for closer economic and political cooperation with Mediterranean countries under the Barcelona Process. The initiative was endowed in ambitious targets of democratization, security and economic growth for the Mediterranean countries together with an unrealistic objective like making peace in the Middle East. It was clear after the years, that it was a yawning gap between the ambitions objectives of the political program and huge obstacles that stood on the way to reaching them.

The accession of Central and East European countries in 2004 and 2007 has shifted external frontiers of the EU far to the East, which intensified the interest of the EU with that area. The idea of that time was to combine two dimensions of the EU's external policy which resulted in establishing new policy framework covering both East neighbors and the Southern Mediterranean partners. On the one hand the Europeans asserted the partner countries they were going to share "everything but institutions", which meant that they were to be treated almost as members. On the other hand, number of visions and interest of each member state of the EU has almost precluded the EU from pursuing coherent policy within the ENP. 


\section{Different interests and visions}

The ENP partner-countries diverge in almost every aspects of their political and socio-economic stance. They differentiate from the level of economic development up to historical and cultural background. This disparity can be also noted in both expectations regarding relations with Europe but also their perceptions and visions towards those relations.

The ENP was conceived to erase the impression on putting new borders between countries which found themselves "in" and "out" of the club. The EU decided to set the tone for the longstanding dialogue by deepening institutional relations and giving greater emphasis to bilateral cooperation with each neighboring country. The problem was that the partner countries had different visions and expectations against the EU's offer. Thus for some countries the EU did not match their political aspirations and economic needs, for others the program was putting too much emphasis on democratization and good governance instead of focusing on trade relations and development assistance. The Southern group of countries perceive the EU activities in the region as a bulk that hinders their maneuvers, while the Eastern partners consider the European engagement as insufficient which may not give them a guarantee for EU's accession (Bendick 2008: 4).

The 16 ENP countries have not very much in common, except several key features such as poor economic performance, poverty, lack of good governance, rule of law, violations of human rights, etc. One of this is the geographic proximity to the EU. However geographical closeness in itself is a weak argument to the importance of mutual relations (Lehne 2014: 6). Good neighboring relations with the EU are much more important factor in a strategic decision-making process taken by the partners. Most of the countries would prefer to hold individual relations with the EU than depend on cooperation with others. This is particularly visible in the Mediterranean states. Due to their long-term historical and cultural relations with Western Europe they seek to maintain individual relations with the EU based on aid programs and development assistance. The propensity of building bilateral relations is also seen in case of the Eastern neighbors. 
The EU's approach to its neighborhood has been often characterized as a Eurocentric attitude where the partners interests were neglected and the needs ignored. The concept which the ENP was based on is assumed largely that the partner countries share the "same values and interests" as the EU member states. This conviction creates a belief that the neighbors should easily adhere to principles such as social cohesion, rule of law, and respect of human rights. It is very hard to accept in particular for Mediterranean countries that the driving force of their evolution and modernization might come from outside on a "carrot stick" policy basis. In their opinion the method taken in the European program clearly shows that the ENP logic was formulated with special attention to Eastern European neighbors than the Southern Mediterranean (R. A. Del Sarto, T. Schumacher 2005: 17-18).

Additionally there are growing disparities even among the countries with geographical proximity such as the Eastern neighbors. Most of them strive to build closer and substantive relationship with the EU, however the ENP does not match the most ambitious interests of these countries (i.e. Ukraine or Georgia) (Lehne 2014: 7). In return the EU has not sent a clear message about eventual accession of these countries, what make them feel uncertain and confused. Georgia clearly considers the ENP as a path towards European integration from the very beginning while Moldova and Ukraine have changed slightly their political positions in the course of time. Armenia has developed a rather pragmatic approach with a clear focus on economic cooperation and Azerbaijan has also limited expectations towards the ENP as the country attached greater importance to cooperation with Russia and Central Asian neighbors (Delcour 2011: 11).

However countries with perspective of future membership perceive the EU's promises as too little. An incentive of accession would be much more powerful force to reform than a blurred perspective on EU's enlargement dispensed in symbolic doses (Delcour 2011). While certain member states, namely from Central Europe deem that Ukraine, Georgia and Moldova should be given a perspective for future membership, a number of other states, mainly from the "old" Europe are skeptical and reserved. For instance country like Moldova is very much interested in closer cooperation with the Union as it is very much dependent on its financial assistance as well as trade relations and considers the EU as a main destination of its job 
seekers. Other states from the Eastern Partnership do not share the same attitude as Moldova. For Azerbaijan the EU is one of its many trading partner and Armenia has recently opted for Euro-Asian customs union with Russian.

The ENP partner countries have been very much influenced by complex and floating situation in neighboring area. The engagement of other state actors such as the US, Turkey, Russia, China, Saudi Arabia or Qatar reduces relative power of the EU by offering financial and material commitments without strict conditionality. The EU is perceived as a institution which put tough requirements in terms of reforms and modernizations and offers too little in return (Youngs 2014: 89-99). Therefore the EU's offer involves burdensome costs for the recipient and long-term procedures of disbursement which make the EU's assistance less attractive.

\section{Southern Mediterranean perspective}

Southern Mediterranean partners perceive the ENP initiative with undisguised reserve. They accused the Europeans of not arranging consultations with the Southern partners before launching the initiative. They felt overlooked because the project was designed especially for Central and Eastern Europe and then it had been extended to the South Mediterranean countries at the last minute (Boumghar 2013: 1-3). First of all they object the ENP instrument which speaks of sharing European values and express the approach based on the European hegemony. The conditionality underpinning the ENP appears to Southern partners as a mechanism which make the impolite pupil set back on the right bank. The post-colonial stigma influences the current South-North relations and makes the Southern partners very much responsive to relations with European counterparts. It correlates strictly to their sensitivity in relation to sovereignty and interference. Despite the critics Mediterranean partners have accepted an argument of conditionality, which means that in case of human rights violation the AAs with a partner country can be suspended. 
Although the initiative seems to be needed and fills some gap in mutual relations, the Southern partners expressed serious reservation concerning the merit of the ENP, which assumes European financial assistance and deepening economic cooperation to be proportional to the progress made in areas such as human rights, rule of law and civil societies development. Instead, the partners would prefer the EU to consider the problems like management of migration or a signature of readmission agreement that to deal with domestic issues related to democratization processes. In the view of Southern partners democratic changes are the results of internal demand that should be handled domestically without any international pressure (Boumghar 2013).

Reservation towards the ENP is reflected by the long-lasting process of establishing free trade area (FTA) between the EU and the Mediterranean countries. The launching of FTA with the EU by 2010 was a key objective within the Barcelona Process. Bilateral FTAs. were included in each Association Agreements and negotiation position of the partners depended on economic development of a country and its profile. The Mediterranean saw the initiative as a imbalanced due to their inferior economic position and the mono-export oriented markets. The asymmetry stems from the fact that the EU is the main commercial partner for most southern Mediterranean countries, whilst the importance of partners covered by the FTA is much smaller for the Europeans. After the years of implementation there has arisen many concerns around the FTA which related to misallocation of resources and trade diversion, fiscal unsustainability of tariff cuts, rising unemployment associated with eventual deindustrialization in the short run (Lorca, Escribano 2015: 9). Final results did not meet the initial goals. First, the coverage of the FTA was restricted to the trade in goods and second only limited number or countries engaged in development of their FTAs both with the EU and with other partner countries in the region (Wouters, Duquet 2013: 37).

After the years of implementation the most advanced Mediterranean partners have been offered a new formula of a free trade agreement. Though the scale and the content of the reforms taken under the AAs were poor, the EU acknowledged to be sufficient for launching a new set of negotiations. The offer of launching negotiations on Deep Comprehensive Free Trade Agreement (DCFTA) was 
addressed to Jordan, Egypt, Tunisia and Morocco. The DCFTA was assumed to be an instrument enabling the countries (both from the Eastern and Southern dimension of the ENP) to create better integration of their economies into the EU single market. The DCFTAs consist of two parts: first - tariff reduction which is built on WTO commitments and second - adoption of EU trade acquis going beyond tariff reductions to cover more extensively the dimensions of investment protection, public procurement and competition policy. They cover all trade-related areas such as services, intellectual property rights, customs, public procurement, energy-related issues, competition, etc.

Most of the Mediterranean partner countries have concluded AAs with the EU which cover trade in industrial goods with some additional protocols on liberalization in agriculture commodities (the AAs were entered into force with Algeria in 2005, Egypt in 2004, Israel in 2000, Jordan in 2002, Lebanon in 2006, Morocco in 2000, Palestine Interim Agreement in 1997 and Tunisia in 1998). However for the time being there has been little chance to implement the provisions of the DCFTA even in the most advanced Southern partners such as Morocco, Jordan or Tunisia.

\section{The Eastern dimension perspective}

The Eastern partners perceive the ENP as a program which did not meet their expectations concerning both economic relations and accession's aspirations. Taking into account deteriorating economic conditions they are not very much willing to bear significant costs of transformations and integrations with the EU, particularly when the ultimate goal of such relationship has not been clearly defied (Sadowski 2013: 9). Despite declarations about "co-ownership" of the ENP initiative, the partner countries do not perceive the EU's model of mutual relations as their own project. Therefore they consider the actions taken by the EU under the ENP as not to be agreed jointly with the partner countries. Their general position towards the initiative depends mostly on current political and economic situation in the regions 
as well as the short-term interest of governments and local politicians (Sadowski 2013: 28).

There are two groups of EaP countries for which cooperation with the EU means something else. The first one with participation of Ukraine, Moldova and Georgia have accelerated negotiations with the EU by signing Association (AA) and the DCFTA in June 2014, and a visa-free regime with Moldova in April 2014. The three other EaP states, Belarus, Armenia and Azerbaijan, have signed up to a Russian-led Eurasian Economic Union (EEU), which has automatically excluded them from joining the DCFTA (Knott 2015). In turn they select and focus these elements of economic cooperation with the EU, which would provide them with better access to European market and transfer of technology. Accordingly they treat their relations with the EU instrumentally by balancing between the EU and Russia. They count on substantial benefits but they have done no progress in economic and political liberalization instead. Belarus is engaged in issues that can not endanger the power of the ruling regime, such as border security, while avoiding cooperation in potentially dangerous areas, such as closer political relations or economic integration. In Azerbaijan current political establishment is much more committed in relation with Russia than with the EU. Relations with the EU are based mainly on energy cooperation, which is seen as a priority for European market. Belarus and Azerbaijan are engaged in economic integration with Russian within the framework of custom union.

The second group of the countries consists of Moldova, Georgia, Ukraine. Their priority in relations with the UE is accession. The problem is that the EU does not guarantee them membership in the nearest future, which consequently leads to weakening of the partner's engagement in the process of integration. Therefore, due to the changing circumstances some of them lose their pro-European enthusiasm. Additionally financial crisis in the Eurozone has shown the ENP partners that the European model of development is not the only option available for them. A competitive project has arisen under the leadership of Russia who offers deeper economic and political cooperation under the Euro-Asian union. As a result Armenia has changed over the time its course of actions towards the EU. Currently the 
country may be positioned somewhere between these two groups, though closer to Belarus and Azerbaijan than to Ukraine or Georgia (Gromadzki 2015: 13).

Despite the fact that Russia was not a formal partner country within the ENP framework, its foreign policy has very much influenced Eastern partners interests and their political position. Russia's attitude towards the ENP and its Eastern dimension has appeared very quickly very hostile and aggressive. All partner countries with the most advances institutional relationships with the EU have became a subject to Russian threats, political and economic sanctions. Russia has asserted pressure on the countries to withdraw from cooperation with the EU and to choose Euro-Asian customs union under its leadership. When the EU completed the DFCTA with Ukraine, Russia decided to react and convinced Kiev to shift the course of its policy. These steps have led to mass proceedings in the Ukrainian Eastern territory and military accession of Crimea. It seems that the Russian intention is destabilization of the Ukrainian's East regions, not to mention about the intimidation of the other states in Eastern European and the Southern Caucasus.

The dilemma of having good relations with Russian together with extending or deepening cooperation with the EU is one of the biggest challenge the Eastern partners are facing. The vast majority of countries are seeking to develop good relations with Western Europe but at the same time trying not to pressing Russian's buttons. They attempt to gain benefits both from the EU and Moscow. Due to their close economic and political ties with Russia they are afraid of deterioration their mutual relations which may result in economic and political sanctions or military rehearsal. The exception is Georgia and Moldova whose politicians have expressed occasionally their independence from Russian influences. Nevertheless they are also forced to pursue cautious policy towards Russia.

The lack of clear defined policy objectives under the ENP has led to the situation in which the politicians from the partner countries treat the EU instrumentally and nearsightedly. Political leaders have often used their relations with the EU to strengthen their political position and to get short-term economic gains. According to R. Sadowski the widening discrepancy between the objective of integration and the timeframes of possible accession makes the politicians from the partner countries less interested in achieving the final goal of the EU' integration 
(Sadowski 213: 32). Additional costs associated with introducing of economic and social reforms would not prevail them on taking the agenda.

\section{Conclusions}

The ENP is weakening. The reason is twofold: different visions and expectations from the partner countries and second a floppy engagement of the UE's institutions in the forging of the ENP coherent policy.

First, different visions and perception of the partner countries towards the ENP come from their divergent interest and concerns. However it can be found a general feature of their approaches which is based on common criticism against the provisions of the program. In consequence each of the partner-country both from the Southern and Eastern dimension of the ENP prefers developing its individual relations with the EU than jointly with others. Second, a weakened political commitment from the EU may result in a departure from the policy objectives such as support for democratic transition and bringing the partner countries closer to the EU (Kaca 2014). In light of the EU's current "post-Arab spring” relations with Mediterranean partners and fragile relations with Russia the EU might take the course to reduce its ambitions in terms of deepening political integration with both regions and limit the EMP and the EaP to technical cooperation.

Most of the partners have so far made little progress in reforms, modernizations and integration with the EU. Since the inception of the ENP in 2004 their internal situation related to democratization, free market transformation or civil society has not very much improved, except some countries from the Eastern Partnership which aspire to EU's membership. Moreover the other countries have not been prepared to bear additional costs for modernization especially when they faced deteriorating economic and social conditions. Moreover the EU is seen as it has been losing interest in the neighborhood policy owing to its internal Euro crisis.

The ENP partners differ in almost every aspect, from their level of social and economic development to security and political situations. In this respect they differ also in approach to outcomes of the ENP and the matter it is pursued. General line 
runs between the partner countries which are very keen on future membership and these who do not aspire to become a member of the EU. The first ones have fulfilled the essential commitments by signing the AAs and DCFTAs. The problem is that the (pro-EU) political class of Georgia, Ukraine and Moldova view the membership option as a panacea, both to shore up uncertain domestic support for EU integration and as a buffer to Russian leverage (Knott 2015). The second group did not expect the enlargement of the EU but they relied on closer but selective economic and political relationships with European members based on greater financial assistance and open access to the European market. They expect from the Europeans to open up their common market for goods and services and a greater admission of labor forces.

The way the ENP is seen by the partner countries varies considerably. In the Mediterranean countries, except Israel, accession to the UE is not taken into account, while the EU's involvement in domestic affairs is perceived negatively. In most cases (i.e. Egypt, Tunisia, Morocco, Algeria, Jordan and Syria) European concern of domestic affairs is highly critical not only by the governments, but also by the representatives of civil society. By contrast partners from the Eastern Partnership initiative criticize the EU for deficient engagement within the ENP and the lack of a key message about the EU's Eastward enlargement. These attitude prevailed specially in Ukraine, Moldova and Georgia. The most difficult partnercountries to qualify are the Palestinian Authority and Belarus. Israel is an another exception. It has good long-standing political and economic relations with the EU, however for the reason of security and geopolitical situation its rapprochement to the EU is quite difficult.

Both the Southern and Eastern partners perceive each other as a rivals in their strive to meet the ENP requirements, particularly in receiving financial assistance. Mediterranean partners would prefer to be in different initiative than together with their counterparts from the Eastern Europe. Accustomed to traditional closer economic relations with the EU they did not like to share the same cooperation platform with Eastern neighbors. In their view a single inclusive approach to both of them may not be applied simultaneously. 


\section{References}

Bendick A. (2008), The ENP. Visibility and perception in the partner countries, „Working Paper", Research Unit EU External Relations, Stiftung Wissenschaft und Politik, German Institute for International and Security Affairs, Berlin.

Boumghar L. (2013), The Algierian position on the European Neighborhood Policy, "Geographical Overview”, Institut National d'Études de StratégieGlobale (INESG), Algiers, IEMed Mediterranean Yearbook, http://www.iemed.org/observatori-en/arees-danalisi/arxiusadjunts/anuari/iemed-2013/Boumghar\%20Algeria\%20ENP\%20EN.pdf [24.03.2017].

Delcour L. (2011), Bringing South Caucasus closer to Europe. Achievements and challenges in ENP implementation, „College of Europe Natolin Research Papers”, no. 03.

Gromadzki G. (2015), Eastern partnership revisited. Associated countries in focus, Stefan Batory Foundation, Friedrich Ebert Stiftung, Warsaw, http://www.batory.org.pl/upload/files/Programy\%20operacyjne/Otwarta\%20Europa/Eastern _Partnership_Revisited.pdf [28.03.2017].

Hett F., Kikić S., Meuser S. (eds.) (2015), Reassessing the European Neighborhood Policy. The Eastern dimension, Friedrich Ebert Stiftung, http://library.fes.de/pdf-files/idmoe/11483.pdf [24.03.2017].

Kaca E. (2014), Is the Eastern partnership weakening? The consequences of the EU institutions’ power shift to neighborhood policy, „PISM Bulletin”, no. 133, 25 November.

Knott E. (2015), Following the Riga summit, more realism is required over what the EU can offer its eastern partners, London School of Economics, http://blogs.lse.ac.uk/europpblog/2015/06/01/following-the-riga-summit-more-realism-isrequired-over-what-the-eu-can-offer-its-eastern-partners/ [22.03.2017].

Koeth W. (2014), The „Deep and Comprehensive Free Trade Agreements”. An appropriate response by the EU to the challenges in its neighborhood?, European Institute of Public Administration, http://www.eipa.eu/files/repository/eipascope/20141120085243_EIPASCOPE_2014_WKO. pdf [22.032017].

Lehne S. (2014), Time to reset the European Neighborhood Policy, Carnegie Europe, http://carnegieeurope.eu/2014/02/04/time-to-reset-european-neighborhood-policy-pub-54420 [01.11.2018]. 
Lorca A., Escribano G. (2015), The Euro-Mediterranean Free Trade Area. From competition to

integration,

http://unpan1.un.org/intradoc/groups/public/documents/CAFRAD/UNPAN013747.pdf [24.03.2017].

Prodi R. (2002), A wider Europe. A proximity policy as the key to stability, Brussels, 5-6 December, http://europa.eu/rapid/press-release_SPEECH-02-619_en.htm [22.03.2017].

Sadowski R. (2013), Partnership in times of crisis. Challenges for the Eastern European countries' integration with Europe, Centre for Eastern Studies, Warsaw.

Sarto R.A., Schumacher T. (2005), From EMP to ENP. What's at stake with the European Neighbourhood Policy towards the Southern Mediterranean?, „European Foreign Affairs Review", no. 10, pp. 17-38.

Wouters J., Duquet S. (2013), The Arab uprisings and the European Union. In search of a comprehensive strategy, „Leuven Centre for Global Governance Studies Working Paper”, no. 98 , Leuven.

Youngs R. (2014), Europe in the new Middle East. Opportunity or exclusion?, Oxford University Press, Oxford. 